\title{
A scientific note on occurrence of pathogens in colonies of honey bee Apis mellifera in Vale do Ribeira, Brazil
}

\author{
Lubiane Guimarães-Cestaro ${ }^{1}$, José Eduardo Serrão ${ }^{2}$, Maria Luisa Teles Marques Florêncio Alves ${ }^{3}$, \\ Dejair Message $^{4}$, Érica Weinstein TeIXeIrA ${ }^{3}$

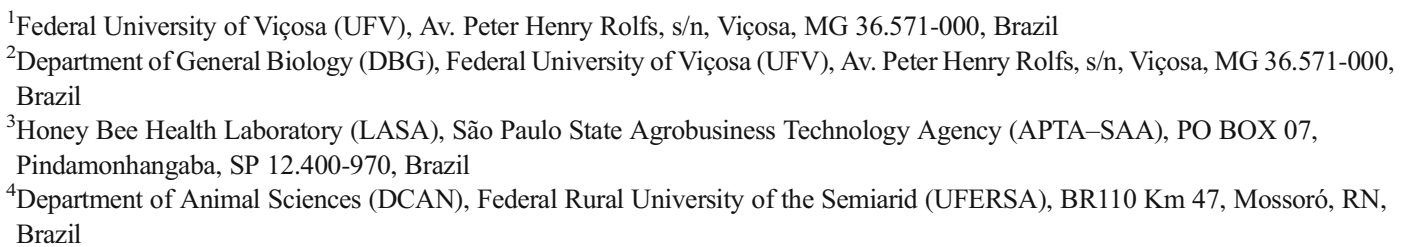

Received 29 February 2016 - Revised 26 September 2016 - Accepted 25 October 2016

\section{Africanized honeybees / Paenibacillus larvae / Nosema ceranae / Nosema apis / Varroa destructor}

In recent times, studies on honey bees have been intensified because of the decline in population of these insects, in various parts of the world, probably on account of the use of pesticides and/or by the action of pathogens (Doublet et al. 2015). On account of this, knowing the health profile of honeybee colonies with the help of preventive monitoring is important. This study evaluates the presence of Nosema apis, Nosema ceranae, Paenibacillus larvae, and Varroa destructor in colonies of the Vale do Ribeira region, State of São Paulo, Brazil.

The samples were collected in April 2013 (autumn season) from 15 apiaries in 10 municipalities of Vale do Ribeira region (Figure 1). All samples were properly packed in the field and transferred to the Honey Bee Health Laboratory of the Polo Regional Vale do Paraíba (LASA/APTA).

To determine the intensity of infection caused by the Nosema spp., the procedure described by Teixeira et al. (2013) was utilized, and this PCR conditions: denatur-

Electronic supplementary material The online version of this article (doi:10.1007/s13592-016-0481-3) contains supplementary material, which is available to authorized users.

Corresponding author: L. Guimarães-Cestaro, lubi.guimaraes@gmail.com

Manuscript editor: Yves Le Conte ation at $94{ }^{\circ} \mathrm{C}$ for $2 \mathrm{~min}, 35$ cycles of $94{ }^{\circ} \mathrm{C}$ for $30 \mathrm{~s}$, $57^{\circ} \mathrm{C}$ for $30 \mathrm{~s}, 72^{\circ} \mathrm{C}$ for $50 \mathrm{~s}$, and elongation at $72^{\circ} \mathrm{C}$ for $5 \mathrm{~min}$. For P. larvae analyses, samples of honey obtained from honeycombs were submitted to the official method of diagnosis (Brazil 2003) and the molecular method proposed by Guimarães-Cestaro et al. (2016). For analyses of $V$. destructor, the method proposed by De Jong et al. (1982) to analyze the infestation rate and Dietemann et al. (2013) to analyze brood combs was used. Adult mites were submitted for DNA extraction (Faza et al. 2013) and PCR reactions using primers suggested by Navajas et al. (2002), following these conditions: denaturation at $92{ }^{\circ} \mathrm{C}$ for $4 \mathrm{~min}, 35$ cycles at $92{ }^{\circ} \mathrm{C}$ for $1 \mathrm{~min}$, annealing at $52{ }^{\circ} \mathrm{C}$ for $90 \mathrm{~s}$, and elongation at $72{ }^{\circ} \mathrm{C}$ for $90 \mathrm{~s}$. Haplotypes $\mathrm{J}$ and $\mathrm{K}$ were identified according Anderson and Fuchs (1998).

Just the specie $N$. ceranae was detected and showed average of intensity of infection of $1,070,000$ spores/bee (Table I, supplementary material). The occurrence of $N$. ceranae as a unique microscoporidium species in honey bee hives has also been reported in samples from other Brazilian regions (Santos et al. 2011, 2014), which reinforce the hypothesis that $N$. ceranae has replaced N. apis in various countries (Teixeira et al. 2013). In the samples analyzed here there is a variation in the number of $N$. ceranae spores, supporting the hypothesis that although $N$. ceranae is widely distributed in Brazil, it does not seem to have an infection pattern throughout the year (Teixeira et al. 2013). However, the high 


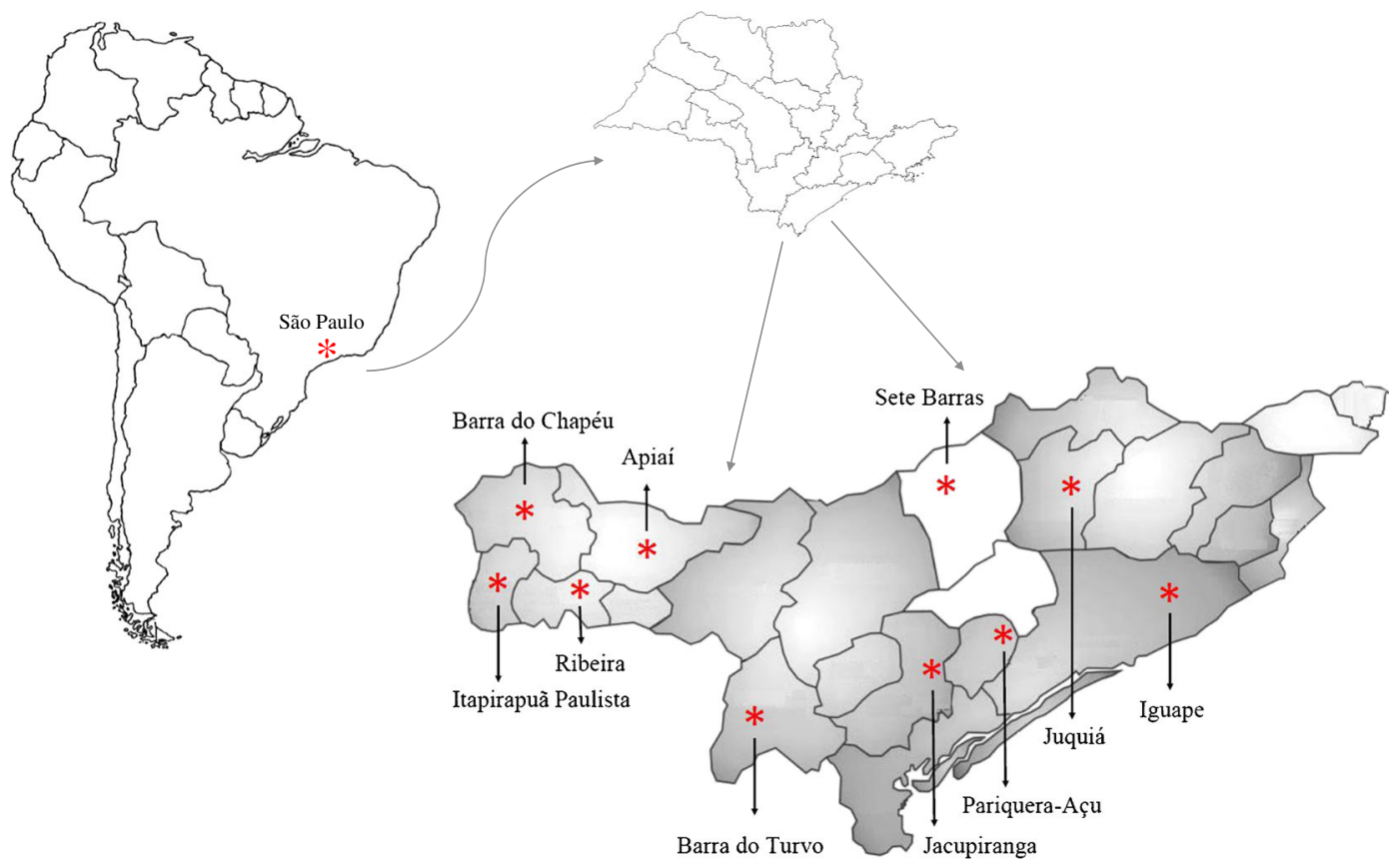

Figure 1. Municipalities in Vale do Ribeira region where the samples were collected: Apiaí $\left(24^{\circ} 30^{\prime} \mathrm{S} 4850^{\prime} \mathrm{O}\right)$,

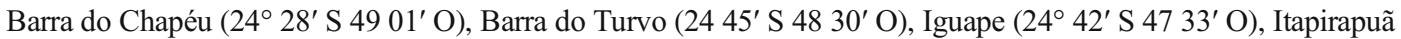
Paulista ( $\left.20^{\circ} 38^{\prime} \mathrm{S} 4713^{\prime} \mathrm{O}\right)$, Jacupiranga ( $\left.24^{\circ} 41^{\prime} \mathrm{S}-48^{\circ} 00^{\prime} \mathrm{O}\right)$, Juquiá ( $\left.24^{\circ} 19^{\prime} \mathrm{S} 4738^{\prime} \mathrm{O}\right)$, Pariquera-Açu (24 $42^{\prime}$

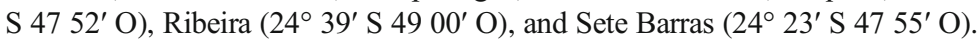

intensity of infection found in autumn may be explained by the cold temperature during this season, which results in the bees remaining in their hives, increasing the potentials of transmission and infection (MartínHernández et al. 2009).

All the 68 samples tested for the presence of P. larvae were negative, showing that, although the sampled municipalities were located about $200 \mathrm{~km}$ from the Municipality of Quatro Barras-PR, the more recent place with report of American Foulbrood in Brazil, this disease was controlled, as all contaminated hives in a $10-\mathrm{km}$ radius around the outbreak were burned (MAPA 2006).

The mean rate of infestation by $V$. destructor was obtained in adult bees and cells of worker bees in brood comb (Table I, supplementary material). The fact that in autumn mites are found in the phoretic phase, feeding mainly on nurse bees may explain the higher infestation rates obtained in autumn compared to those in summer (Santos et al. 2011, 2014). Our findings about cells infested with offspring (from 0 to 5.12) support the hypothesis that females show reduced fertility in South America (Rosenkanz and Engels, 1994), where the authors found average number of 3.3-4.1. In addition, our data contradict the information given by Garrido et al. (2003) that the increased fertility in the
V. destructor females has been attributed to haplotype $\mathrm{K}$. In this study, all samples have haplotype $\mathrm{K}$, without causing great damage to beekeepers (Moretto et al. 1991).

The microsporidian N. ceranae was present in $80 \%$ of samples, confirming the prevalence of this species in another region of the State of São Paulo, as well as the $V$. destructor mite, present in $98.8 \%$ of the samples of adult bees and $79 \%$ of the combs. Trade of bee products and their globalization issues can play an important role in the spread of pathogens and expansion assessments as presented in this study generate information on which grants to government guidelines, by through knowledge of the health of the national squad profile.

\section{ACKNOWLEDGEMENT}

This work was supported by the São Paulo Research Foundation (FAPESP, EWT 2012/18802-3). We thank the Coordination for the Improvement of Higher Education Personnel (CAPES) for the scholarship funding and the São Paulo State Agribusiness Technology Agency (APTA, SAA-SP) for the institutional support. JES is a research fellow of the National Council for Scientific and Technological Development (CNPq) and Minas Gerais Research Foundation (FAPEMIG). 
Authors' contributions LGC: Carried out analysis of Nosema spp., Varroa destructor and P. larvae and contributed to write this article; JES: Carried out analysis of Nosema spp. and contributed to write this article; MLTMFA: Carried out the collections and analyzis of Varroa destructor and P. larvae and contributed to write this article; DM: Carried out analysis of Nosema spp. and contributed to write this article; EWT: Carried out the collections and contributed to write this article.

\section{REFERENCES}

Anderson, D.L., Fuchs, S. (1998) Two genetically distinct populations of Varroa jacobsoni with contrasting reproductive abilities on Apis mellifera. J. Apic. Res. 37 (2), 69-78

Brasil (2003) Ministério da Agricultura e do Abastecimento. Instrução Normativa $n^{\circ} 62$, de 26 de agosto de 2003. Métodos Analíticos Oficiais para Análises Microbiológicas para Controle de Produtos de Origem Animal. Anexo, Capítulo XIX Pesquisa de Paenibacillus larvae subsp. larvae. Diário Oficial da União. [online] http://www.extranet.agricultura.gov.br/sislegisconsulta/ servlet/VisualizarAnexo?id-6078 (Accessed on 31 Jan 16)

De Jong, D., Roma, D. A., Gonçalves, L.S. (1982) A comparative analysis of shaking solutions for the detection of Varroa jacobsoni on adult honey bees. Apidologie. 13 (3), 297-306

Dietemann, V., Nazzi, F., Martin, S., Anderson, D. L., Locke, B., Delaplnae, K. S., Wauquiez, Q., Tannahill, C., Frey, E., Ziegelmann, B., Rosenkranz, P., Ellis, J. D. (2013) Standard methods for Varroa research. J. Apic. Res. 52 (1). 10.3896/ IBRA.1.52.1.09

Doublet, V., Natsopoulou, M. E., Zschiesche, L., Paxton, R. J. (2015). Within-host competition among the honey bees pathogens Nosema ceranae and Deformed wing virus is asymmetric and to the disadvantage of the virus. J. Invertebr. Pathol. 124, 31-34

Faza, A. P., Pinto, I. S. B., Fonseca, I., Antunes, G. R., De Oliveira, M. O. C. M., Daemon, E., Muniz, M. S., Martins, M. F., Prata, M. C. A., Furlong, J. (2013) A new approach to characterization of the resistance of populations of Rhipicephalus microplus (Acari: Ixodidae) to organophosphate and pyrethroid in the state of Minas Gerais, Brazil. Exper. Parasitol. 134 (4), 519-23
Garrido, C., Rosenkranz, P., Paxton, R. J., Gonçalves, L. S. (2003) Temporal changes in Varroa destructor fertility and haplotype in Brazil. Apidologie. 34 (6), 535-541

Guimarães-Cestaro, L., Serrão, J. E., Message, D., Martins, M. F., Teixeira, E. W. (2016) Simultaneous detection of Nosema spp., Ascosphaera apis and Paenibacillus larvae in honey bee products. J. Hymenoptera Res., 49, $43-50$

MAPA. Nota técnica DSA n52/2006. Ocorrência de "Cria Pútrida Americana" no município de Quatro Barras, estado do ParanáBrasil. Ministry of Agriculture of Brasil, Brasília, 2006

Martín-Hernández, R., Meana, A., García-Palencia, P., Marín, P., Botías, C., Garrido-Bailón, E., Barrios, L., Higes, M. (2009) Effect of temperature on the biotic potencial of honey bee microsporidia. Appl. Environm. Microbiol. 75 (8) 2554-2557

Moretto, G., Gonçalves, L. S., De Jong, D., Bichuette, M. Z. (1991) The effects of climate and bee race on Varroa jacobsoni Oud. Infestations in Brazil. Apidologie. 22 (3), 197-203

Navajas, M., Solignac, M., Le Conte, Y., Cros-Arteil, S., Cornuet, J. M. (2002) The complete sequence of the mitochondrial genome of the honey-bee ectoparasite Varroa destructor (Acari: Mesostigmata). Mol. Biol. Evol. 19 (12), 2313-2317

Puker, A. (2011) PCR multiplex para detecção de patógenos de Apis mellifera L. (Hymenoptera, Apidae) em mel. [online] http://www.locus.ufv.br/handle/123456789/3954 (Accessed on 02 Feb 16)

Rosenkranz, P., Engels, W. (1994) Infertility of Varroa jacobsoni females after invasion into Apis mellifera worker brood as a tolerance factor against varroatosis. Apidologie. 25, 402-411

Santos, L.G., Teixeira, E. W., Alves, M. L., Message, D. (2011) Apicultura Migratória, aspectos sanitários, in: $5^{\circ}$ Congresso Interinstitucional de Iniciação Científica [online] http:// www.iac.br/areadoinstituto/ciiciac/resumo2014/RE14301.pdf (Accessed on $02 \mathrm{Feb} 16$ )

Santos, L.G., Alves, M. L., Message, D., Pinto, F. A, Teixeira, E. W. (2014) Honey Bee Health in Apiaries in the Vale do Paraíba, São Paulo State, Southeastern Brazil. Sociobiology 61 (3), 307-312

Teixeira, E. W., Santos, L. G., Sattler, A., Message, D., Alves, M. L. T. M. F., Martins, M. F., Grassi-sella, M. F., Francoy, T. M. (2013) Nosema ceranae has been present in Brazil for more than three decades infecting Africanized honey bees. J. Invertebr. Pathol. 114, 250-254 